\title{
Adolescents with Personality Disorders: A Systematic Review
}

\author{
Olubukola Akanni ${ }^{1}$, Prince Jacob ${ }^{2}$ \\ ${ }^{1}$ Department of Psychology, Atlantic International University, Hawaii, USA \\ ${ }^{2}$ Academic Advisor, Atlantic International University Hawaii, USA
}

\begin{abstract}
Personality Disorder is a mental health disorder recognized by the International Classification of Diseases (ICD) and the Mental Disorders Diagnostic and Statistical Manual (DSM). Personality Disorder refers to personality characteristics that, for a prolonged period, are maladaptive, inflexible, and pervasive in many contexts, causing severe discomfort and disability. The study was DSM-5 lists three clusters of personality disorders with ten specific disorders in those categories. An adolescent must meet the DSM-5 requirements to be diagnosed with a personality disorder. The primary aim of this article is to review research documenting the underlying mental health problems in personality disorders amongst adolescents and, to evaluate research on potential intervention for such disorders.
\end{abstract}

Eligibility criteria: This systematic review has exclusion and inclusion criteria that were applied to the search results of publication within the last 20 years and included personality and adolescence in the title.

Results: Nineteen studies were considered out of sixty (60) primary studies, of which $19(31.66 \%)$ satisfied the inclusion criteria. The primary studies reviewed personality disorder in childhood/adolescence and the screening for personality disorder in adolescents and impaired functioning from adolescence to adulthood. Personality Disorder was predominately measured using the Structured Clinical Interview for DSM Axis II disorders $(n=9)$, the Diagnostic Interview for GHQ \& SIPP $(n=$ $2)$, and DSM criteria based psychiatric evaluation $(n=8)$. The primary studies utilized cross-sectional, case-control. Studies comprised a mix of clinical and non-clinical populations and ranged in duration from 10 to 24 years.

Conclusions: Adolescent personality has significant genetics and environmental impact. This systematic review shows that many adolescents display behaviour to a certain degree, making it challenging to differentiate mental health disorder and normal adolescent behaviour from a personality disorder. A significant clue is when adolescents have recurrent issues or defiance and when these behaviours are getting more severe. Adolescents at risk of PDs may also be having substance abuse disorder, including alcohol, which exacerbates depression or anxiety. The self-reported data provided very few cases that met diagnostic requirements for personality disorders in adolescence. Hence, more studiesare still needed.

Keywords: Adolescent, personality disorders, mental health, anxiety, depression.

\section{INTRODUCTION}

The word personality originates from the Latin expression 1 persona, initially reflecting the theatrical mask used by ancient dramatic players. Persona indicates a pretence of appearance: the possession of characteristics other than those that define the person behind the mask, as a mask assumed by an actor. (Millon et al., 2012)

Two similar words, character, and temperament are frequently mistaken for personality. While all three words in casual use have similar meanings, a character refers to attributes acquired during childhood and connotes a degree of compliance with ethical, social norms. On the other hand, temperament applies not to socializing factors but to a specific biological inclination towards such activities. One individual may be said to be of "good character," and another individual may have an "irritable temperament." The character, thus, reflects the crystallized influence of nurture, and the physically coded influence of nature is expressed by temperament.

Personality traits can be defined by genes, influenced by the environment, and motivated by Nature, Nurture and Structure (Akanni, 2020).

\section{Nurture}

The character represents the sum of all personality factors that originate from organizational levels in which the individual is embedded, including family, peers, and community. Personality is the dynamic interaction of both character and disposition factors, environment, and the patterning of characteristics across the person's entire existence.

\section{Nature}

Temperament reflects the amount of all personality factors from organizational levels below the individual, including neurotransmitter profiles and, more specifically, genes. Nonetheless, childhood verbal abuse is likely to hurt the development of interpersonal relationships during childhood and adolescence.

During childhood, maternal verbal abuse was more than three times as likely as those who did not experience verbal abuse to have borderline, narcissistic, obsessive-compulsive, and paranoid PDs during adolescence or early adulthood. (Johnson et al., 2001) 
Personality Disorder is a mental health disorder recognized by the International Classification of Diseases (ICD) and the Mental Disorders Diagnostic and Statistical Manual (DSM). Personality Disorder refers to personality characteristics that, for a prolonged period, are maladaptive, inflexible, and pervasive in many contexts, causing severe discomfort and disability.

Childhood verbal abuse can also raise the risk of developing PDs by raising the probability that young people will encounter intensely maladaptive thoughts and emotions, such as distrust, shame, doubt, guilt, inferiority, and identity diffusion during their most crucial years of psychosocial devolution, even though several studies have explored connections between physical and sexual exploitation of adolescents and PDs. (Fonagy \& Luyten, 2016).

Personality disorders are characterized in adolescents by four primary symptoms, according to research:

- Thinking and perception are skewed.

- Problematic emotional reactions

- Impulse regulation that is either over-or underregulated

- Difficulty interacting with others and maintaining relationships.

These four characteristics interact in various ways to shape the ten personality disorders listed in the fifth edition of the Diagnostic and Statistical Manual of Mental Disorders (DSMV).

It should be noted that various pathways can lead to disorders of personality. Narcissistic, obsessive-compulsive, paranoid, and antisocial disorder, for instance, may, through improving applicable policies by significant others or both, result in compensation or as fear, i.e., because of a sense of chaos, coercion, or victims. The value of identification with other members of the family cannot be ignored. Personality problems tend to develop in most people from the inheritance of a strong predisposition.

A personality disorder is a form of mental health disorder that usually begins in adolescence. As a result, an adolescent personality disorder can significantly disrupt the development of adolescent identity, relationship, and emotional control. Furthermore, untreated personality disorders can contribute to social isolation and drug abuse.

Personality disorders usually include unhealthful patterns of thought, functioning, and behaviour. Adolescents with personality disorders have trouble recognizing and communicating with others and their environment. Therefore, their family relations, social life and academic success may be affected. To be diagnosed with a personality disorder, the adolescent must meet the requirements set out in the DSM-5 for that disorder. The diagnosis of adolescent personality disorder also includes that symptoms trigger difficulties in everyday life. (Westen et al., 2006).
Each person has a collection of unique personality traits that make up his or her personality. Personality can be characterized as identifiable and permanent characteristics and attitudes expressed in thoughts, feelings, and actions (pulse control, establishing and managing interpersonal relationships). Personality has developed and evolved since infancy and during life.

Temperament is a biologically defined characteristic that has been evident since birth. Temperamental characteristics display a high degree of maturity and are developmentally correlated with personality traits during adulthood, including extraversion or high energetic level, congeniality, conscientiousness, neuroticism, and openness.

Parenting has a demanding job specification that allows it to be in good mental health. Parents must manage their own negative emotions, not react to stress or anxiety with anger, aggression, cruelty, or panic. Parents need a perfect test of reality. (McAdams \& Olson, 2010) As in any other work, even in most resilient parents, daily life events can temporarily disrupt parenting skills. Relationship breakdown, work stress, physical illness or mild mental disorders can contribute to temporary parenting performance impairment. More psychiatric severe disorders can lead to more severe parental disability (Royal College of Psychiatrists, 2011).

Maternal personality disorder can have an indirect effect on children's growth by influencing how families are planned and constituted. Women with borderline personality disorder appear to have severe and dysfunctional intimate relationships with other people.

In infancy, children develop theory of minds: a collection of psychological capabilities that control their internal psychology and social psychological skills. Parental behaviour and mental state are environments that interact with a child's genetic vulnerability or resilience to influence the development of emotional and mental abilities. Ellis (2008) indicates that some conditions can affect even the most resilient adolescent. Parental harshness, chronic aggression and rejection are behaviours or actions that tend to be especially harmful or dangerous to the developing child. They are also a theory of mind or behaviour that may be more prevalent in parents with personality disorders and give rise to certain forms of 'maladaptive parental behaviour' correlated with high child and adolescent psychology (Johnson, 2001).

\section{MATERIAL AND METHOS}

\section{Criteria of Inclusion and Exclusion}

All systematic review standards are followed. According to Moher et al. and the PRISMA Group (2009), exclusion and inclusion criteria were applied to the search results. Necessary but not exclusive elements of this inclusion criterion included items that had to be published within the last 20 yearsand include personality and adolescence in the title. Something devoid of content has been published in a peer-reviewed 
academic journal as a research article or as a follow-up to another research piece.

The studies were conducted in mainstream educational settings concerned students who were identified to have a personality disorder. They included indicators of interventions, supports, and services and education levels that ranged from primary school. The preliminary studies failed to reach a consensus on what PD means, showing a lack of agreement about the term's definition. Personality Disorder is a mental health disorder recognized by the International Classification of Diseases (ICD) and the Mental Disorders Diagnostic and Statistical Manual (DSM). Personality Disorder refers to personality characteristics that, for a prolonged period, are maladaptive, inflexible, and pervasive in many contexts, causing severe discomfort and disability.

In contrast, others conceptualized it as a form of neurodiversity, "to be accepted and tolerated just like other human differences". The flowchart in Figure 2 represents the screening process using PRISMA. The primary search strategy initially performed two stages of research. First, titles and abstracts were checked to find the most promising papers. Studies incorporated into the product, which was subjected to a second screening, were evaluated through a full-text search. Our overall screening process, which consisted of various stages, identified nineteen studies that met the criteria.

\begin{tabular}{|c|c|c|c|c|c|c|c|}
\hline Authors & Year & $\begin{array}{c}\text { Countr } \\
\mathrm{y}\end{array}$ & Sample (n, age) & Study design & Control Group & Assessment (Cut-Point) & PD FACTORS \\
\hline Chen et al & 2008 & USA & $\begin{array}{c}\mathrm{n}=736 ;(<20 \text { years }) \\
\mathrm{M}=13.7 \text { years }\end{array}$ & $\begin{array}{l}\text { Longitudinal } \\
\text { study }\end{array}$ & $\begin{array}{l}\text { Axis I disorder or PD } \\
\text { Adolescents with Axis I } \\
\text { disorder or PD or both. }\end{array}$ & $\begin{array}{l}\text { Child Behavior Checklist, } \\
\text { Teacher's Report Form and } \\
\text { Youth Self Report }\end{array}$ & $\begin{array}{l}\text { Higher odds of pain and } \\
\text { physical } \\
\text { illness and poorer physical } \\
\text { health and a more rapid decline } \\
\text { in physical health }\end{array}$ \\
\hline $\begin{array}{l}\text { Paul } \\
\text { Moran } \\
\text { etal }\end{array}$ & 2016 & UK & $\begin{array}{c}\mathrm{n}=8(24-25 \text { years }) \\
\mathrm{n}=10(34-35 \text { years })\end{array}$ & $\begin{array}{l}\text { Longitudinal } \\
\text { cohort study }\end{array}$ & $\begin{array}{l}\text { 2-item General Health } \\
\text { Questionnaire (GHQ- } \\
12)\end{array}$ & $\begin{array}{l}\text { the Standardised } \\
\text { Assessment of Personality }\end{array}$ & $\begin{array}{c}\text { Depressive disorder, anxiety } \\
\text { disorder, smoking and alcohol } \\
\text { consumption, illicit substance } \\
\text { use, }\end{array}$ \\
\hline $\begin{array}{l}\text { Gwen et } \\
\text { al. }\end{array}$ & 2012 & UK & $\begin{array}{l}(10-15 \text { years }) \\
(16-21 \text { years }) \\
M=13.7 \text { years }\end{array}$ & Cross sectional & $\begin{array}{l}\text { Axis I and Axis II } \\
\text { disorders }\end{array}$ & $\begin{array}{l}\text { Psychopathy Checklist - } \\
\text { Youth Version (PCL-YV) } \\
\text { and the Structured } \\
\text { Assessment of Violence } \\
\text { Risk in Youth (SAVRY) } \\
\end{array}$ & $\begin{array}{l}\text { Avoidance and internalized } \\
\text { emotional dysregulation, } \\
\text { characterized by preoccupying } \\
\text { anxieties. }\end{array}$ \\
\hline Jean et al. & 2018 & Canada & $\begin{array}{c}\mathrm{n}=8(24-25 \text { years }) \\
10(34-35 \text { years }) \\
\mathrm{M}=11 \text { years }\end{array}$ & $\begin{array}{l}\text { Clinical and } \\
\text { epidemiological } \\
\text { studies }\end{array}$ & $\begin{array}{l}\text { Axis I and Axis II } \\
\text { disorders }\end{array}$ & $\begin{array}{l}\text { Diagnostic Interview for } \\
\text { Borderlines-Revised and } \\
\text { the Childhood Interview } \\
\text { for DSM-V }\end{array}$ & $\begin{array}{l}\text { Avoidant/Abandonment, } \\
\text { unstable interpersonal } \\
\text { relationships, identity } \\
\text { disturbance, impulsivity, } \\
\text { suicidal and self-mutilating } \\
\text { behaviors } \\
\end{array}$ \\
\hline Ilariaet al & 2018 & Italy & $\begin{array}{c}\mathrm{n}=562(13-19 \text { years }) \\
\mathrm{M}=16.24\end{array}$ & Cross sectional & $\begin{array}{c}\text { SIPP-118 is a } \\
\text { dimensional measure }\end{array}$ & $\begin{array}{l}\text { Symptom Check List-90- } \\
\text { Revised (SCR-90) }\end{array}$ & $\begin{array}{l}\text { Internalizing behavior } \\
\text { Externalizing behavior }\end{array}$ \\
\hline $\begin{array}{l}\text { Patricia et } \\
\text { al. }\end{array}$ & 2006 & USA & $\mathrm{n}=54(1-10$ years $)$ & Cross sectional & $\begin{array}{l}\text { Axis I and Axis II } \\
\text { disorders }\end{array}$ & $\begin{array}{l}\text { Child Behavior Checklist, } \\
\text { Teacher's Report Form and } \\
\text { Youth Self Report }\end{array}$ & $\begin{array}{l}\text { Internalizing behavior } \\
\text { Externalizing behavior }\end{array}$ \\
\hline $\begin{array}{c}\text { Thomas et } \\
\text { al }\end{array}$ & 2001 & USA & $\mathrm{n}=54(9-12$ years $)$ & $\begin{array}{l}\text { Clinical and } \\
\text { epidemiological } \\
\text { studies }\end{array}$ & $\begin{array}{c}\text { Axis I and Axis II } \\
\text { disorders } \\
,\end{array}$ & $\begin{array}{c}\text { Symptom scales for } \\
\text { histrionic, borderline, and } \\
\text { narcissistic personality } \\
\text { disorders, Antisocial } \\
\text { behaviour } \\
\end{array}$ & $\begin{array}{l}\text { Co-occurring internalizing } \\
\text { andexternalizing } \\
\text { Symptoms, emotional distress }\end{array}$ \\
\hline $\begin{array}{l}\text { Barbara } \\
\text { De et al }\end{array}$ & 2003 & $\begin{array}{l}\text { Belgiu } \\
\mathrm{m} .\end{array}$ & $\begin{array}{c}\mathrm{n}=419(12-18 \text { years }) \\
\mathrm{M}=16 \text { years }\end{array}$ & Cross sectional & $\begin{array}{c}\text { Axis II of the } \\
\text { Diagnostic and } \\
\text { Statistical Manual of } \\
\text { Mental Disorders } \\
\text { (DSM-IV) } \\
\end{array}$ & $\begin{array}{l}\text { Wisconsin Personality } \\
\text { Disorders Inventory }\end{array}$ & $\begin{array}{c}\text { Neuroticism, Internalizing } \\
\text { behavior } \\
\text { Externalizing behavior }\end{array}$ \\
\hline $\begin{array}{c}\text { Johnson et } \\
\text { al }\end{array}$ & 2000 & USA & $\begin{array}{c}\mathrm{n}=816(17-28 \text { years }) \\
\mathrm{M}=22 \text { years }\end{array}$ & $\begin{array}{l}\text { Clinical and } \\
\text { epidemiological } \\
\text { studies }\end{array}$ & $\begin{array}{l}\text { Axis I and Axis II } \\
\text { disorders }\end{array}$ & $\begin{array}{c}\text { Diagnostic Interview } \\
\text { Schedule for Children } \\
\text { (DISC-I), the Personality } \\
\text { Diagnostic Questionnaire, } \\
\text { the Disorganizing Poverty } \\
\text { Interview } \\
\end{array}$ & $\begin{array}{l}\text { Internalizing behavior } \\
\text { Externalizing behavior }\end{array}$ \\
\hline $\begin{array}{l}\text { Johnson et } \\
\text { al. }\end{array}$ & 2008 & USA & $\mathrm{n}=816(14-16$ years $)$ & Cross sectional & $\begin{array}{l}\text { Axis I and Axis II } \\
\text { disorders }\end{array}$ & $\begin{array}{c}\text { the Personality Diagnostic } \\
\text { Questionnaire, the } \\
\text { Disorganizing Poverty } \\
\text { Interview } \\
\end{array}$ & $\begin{array}{l}\text { Internalized emotional } \\
\text { dysregulation, characterized by } \\
\text { preoccupying anxieties. }\end{array}$ \\
\hline $\begin{array}{l}\text { Sohye et } \\
\text { al. }\end{array}$ & 2014 & USA & $\begin{array}{c}\mathrm{n}=\mathrm{N} / \mathrm{R}(14-16 \\
\text { years })\end{array}$ & $\begin{array}{c}\text { Clinical and } \\
\text { epidemiological } \\
\text { studies } \\
\end{array}$ & $\begin{array}{l}\text { Axis I and Axis II } \\
\text { disorders }\end{array}$ & $\begin{array}{c}\text { Cognitive Emotion } \\
\text { Regulation Questionnaire } \\
\text { (CERQ) }\end{array}$ & $\begin{array}{l}\text { Internalizing behavior } \\
\text { Externalizing behavior }\end{array}$ \\
\hline
\end{tabular}




\begin{tabular}{|c|c|c|c|c|c|c|c|}
\hline Kim et al. & 2008 & USA & $\mathrm{n}=411$ & $\begin{array}{c}\text { Clinical and } \\
\text { epidemiological } \\
\text { studies } \\
\end{array}$ & $\begin{array}{l}\text { DSM-IV Axis-II } \\
\text { personality disorders }\end{array}$ & $\begin{array}{c}\text { Child Behavior Checklist, } \\
\text { Teacher's Report Form and } \\
\text { Youth Self Report } \\
\end{array}$ & $\begin{array}{l}\text { (a) Cluster B symptoms, } \\
\text { (b) externalizing symptoms, } \\
\text { (c) internalizing symptoms }\end{array}$ \\
\hline Kirsten & 2017 & $\begin{array}{l}\text { Netherl } \\
\text { ands }\end{array}$ & $\begin{array}{c}\mathrm{n}=62(16-23 \text { years }) \\
\mathrm{M}=18.2\end{array}$ & Cross sectional & $\begin{array}{l}\text { Structured Clinical } \\
\text { Interview for DSM } \\
\text { personality disorders } \\
\text { and the Symptom } \\
\text { Check List } 90\end{array}$ & $\begin{array}{c}\text { Structured Assessment of } \\
\text { Violence Risk in Youth } \\
\text { (SAVRY) }\end{array}$ & $\begin{array}{c}\text { Paranoid; Schizoid; Schizotypal; } \\
\text { Antisocial; Borderline; } \\
\text { Histrionic; Narcissistic; } \\
\text { Avoidant; Dependent; Obsessive } \\
\text { compulsive; Depressive; Passive } \\
\text { aggressive } \\
\end{array}$ \\
\hline Carla & 2017 & USA & $\mathrm{n}=110(<18$ years $)$ & Cross sectional & DSM-5 section II BPD & $\begin{array}{c}\text { Borderline Personality } \\
\text { Questionnaire (BPQ) }\end{array}$ & $\begin{array}{l}\text { Internalizing behavior } \\
\text { Externalizing behavior }\end{array}$ \\
\hline Carla & 2018 & USA & $n=69(4-22$ years $)$ & $\begin{array}{l}\text { Longitudinal } \\
\text { cohort study }\end{array}$ & $\begin{array}{c}\text { DSM-IV clusters with } \\
\text { baseline assessment at } \\
\text { age } 9\end{array}$ & $\begin{array}{l}\text { McLean Study of Adult } \\
\text { Development }\end{array}$ & $\begin{array}{c}\text { Personality pathology and } \\
\text { independent } \\
\text { of internalizing and } \\
\text { externalizing pathology }\end{array}$ \\
\hline $\begin{array}{l}\text { Eunice et } \\
\text { al. }\end{array}$ & 2017 & UK & $\begin{array}{c}\mathrm{n}=366(12-17 \\
\text { years })\end{array}$ & $\begin{array}{l}\text { Longitudinal } \\
\text { cohort study }\end{array}$ & $\begin{array}{c}\text { Structured Clinical } \\
\text { Interview for DSM-IV } \\
\text { Axis II (SCID-II) }\end{array}$ & $\begin{array}{l}\text { Treatment in Suicidal } \\
\text { Teenagers study, ASSIST }\end{array}$ & Depression; Suicidal ideation \\
\hline $\begin{array}{l}\text { Salome } \\
\text { etal }\end{array}$ & 2017 & USA & $\begin{array}{c}\mathrm{n}=301(12-17 \\
\text { years }) \\
\mathrm{M}=15.22\end{array}$ & Cross sectional & $\begin{array}{l}\text { Childhood Interview } \\
\text { for DSM-IV Borderline } \\
\text { Personality Disorder }\end{array}$ & Youth Self-Report & Antisocial peers \\
\hline Sylia et al & 2019 & USA & $\begin{array}{c}\mathrm{n}=998(14-24 \\
\text { years }) \\
\mathrm{M}=17.90\end{array}$ & $\begin{array}{l}\text { Longitudinal } \\
\text { cohort study }\end{array}$ & $\begin{array}{l}\text { Structured Clinical } \\
\text { Interview for DSM-IV } \\
\text { Axis II (SCID-II) }\end{array}$ & $\begin{array}{c}\text { Multidimensional } \\
\text { Personality Questionnaire }\end{array}$ & $\begin{array}{c}\text { Oppositional defiant disorder, } \\
\text { conduct disorders, Substance } \\
\text { use disorder, major depressive, } \\
\text { Anxiety disorders }\end{array}$ \\
\hline
\end{tabular}

Summary of Hypothetical Meta-Analytic Results of PD in Adolescents

\begin{tabular}{|c|c|c|c|c|c|c|c|}
\hline & $\begin{array}{l}\text { Cohen's } \\
\text { d (95\% CI) }\end{array}$ & Q & $\begin{array}{l}\mathrm{I}^{2} \text { squared }(95 \% \\
\mathrm{CI})^{\mathrm{b}}\end{array}$ & $\mathrm{P}^{*}$ & $\begin{array}{c}\text { Trim } \\
\text { and Fill }\end{array}$ & $\begin{array}{c}\text { Begg and } \\
\text { Mazumdar's } \\
\text { Test }\end{array}$ & $\begin{array}{c}\text { Egger's } \\
\text { Test }\end{array}$ \\
\hline $\begin{array}{l}\text { Higher odds of pain and physical illness and a more rapid } \\
\text { decline in physical health }\end{array}$ & $5.71(3.2 ; 1.3)$ & 6.8392 & $(0.00,10.02)$ & .082 & 1 & 5 & 0 \\
\hline $\begin{array}{c}\text { Depressive disorder, anxiety disorder, smoking and alcohol } \\
\text { consumption, illicit substance use, }\end{array}$ & $6.25(3.8 ; 1.1)$ & 6.8710 & $(0.00,11.03)$ & .067 & 0 & 8 & 0 \\
\hline $\begin{array}{l}\text { Antisocial peers, oppositional defiant disorder, conduct } \\
\text { disorders }\end{array}$ & $4.46(4.0 ; 1.0)$ & 6.6134 & $(0.00,12.04)$ & .095 & 5 & 2 & 0 \\
\hline $\begin{array}{l}\text { Avoidance and internalized emotional dysregulation, } \\
\text { characterized by preoccupying anxieties. }\end{array}$ & $4.35(3.7 ; 1.3)$ & 6.6771 & $(0.00,22.00)$ & .082 & 8 & 5 & 0 \\
\hline $\begin{array}{l}\text { Avoidant/Abandonment, unstable interpersonal } \\
\text { relationships, identity disturbance, impulsivity }\end{array}$ & $4.76(3.3 ; 1.5)$ & 6.6932 & $(0.00,26.05)$ & .099 & 2 & 7 & 0 \\
\hline Internalizing behavior and Externalizing behavior & $5.78(4.1 ; 1.1)$ & 6.0790 & $(0.00,16.00)$ & .095 & 4 & 1 & 0 \\
\hline $\begin{array}{l}\text { Paranoid; Schizoid; Schizotypal; Antisocial; Obsessive } \\
\text { compulsive; Depressive; Passive aggressive }\end{array}$ & $6.11(2.7 ; 1.2)$ & 6.8901 & $(0.00,35.02)$ & .071 & 6 & 1 & 0 \\
\hline
\end{tabular}

Note. $\mathrm{k}=$ number of studies; $\mathrm{N}=$ total number of participants; Cohen's $\mathrm{d}=$ standardized mean difference; $\mathrm{CI}=$ confidence interval, $* * \mathrm{p}<.001$

Fig 1: Hypothetical Meta-Analytic Results of Personality Disorders in Adolescents

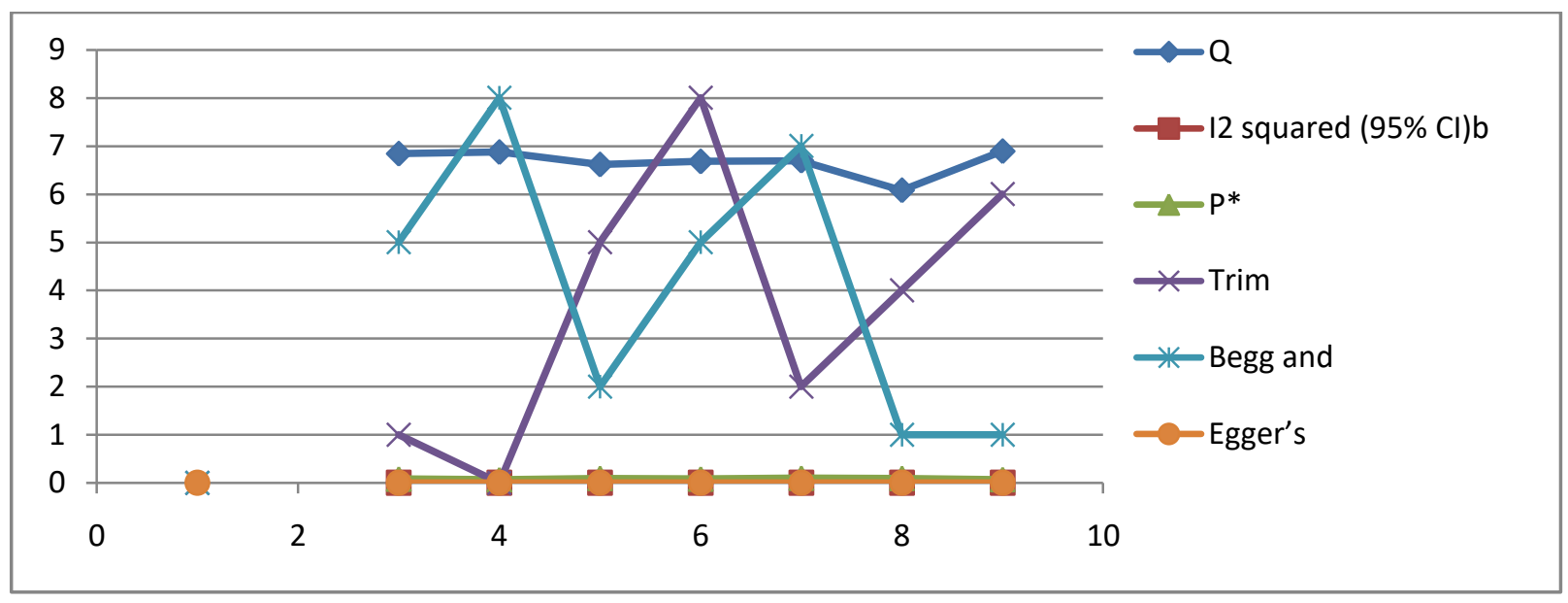




\section{SELECTION CRITERIA}

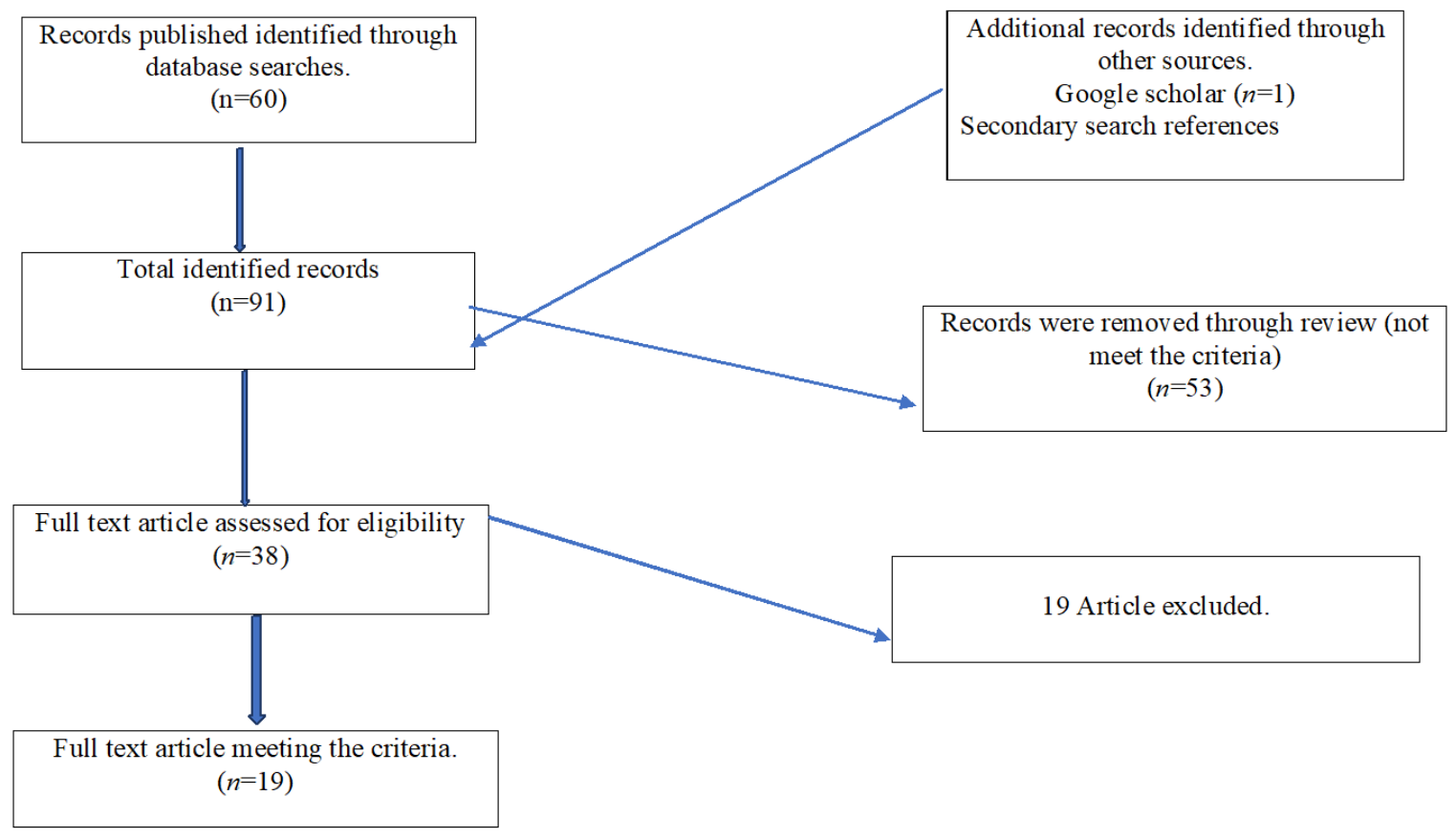

\section{DEMOGRAPHIC RESULTS}

Nineteen (19) studies were reviewed with sample age below > 10years (Gwen et al., 2012; Patricia et al., 2006; Thomas et al., 2001; Kim et al., 2008; Carla, 2018). Eleven studies showed age samples ranged from $>10$ years but not more than 22 years (Chen et al., 2008; Gwen et al., 2012; Ilaria etal., 2018; Thomas et al., 2001; Barbara De et al., 2003; Johnson et al., 2008; Sohye etal., 2014; Carla, 2017; Carla, 2018; Eunice et al., 2017; Salome et al., 2017). Seven (7) studies`age samples ranged from $<22$ years were defined by (Paul Moran et al., 2016; Jean et al., 2018; Johnson et al., 2000; Kim et al., 2008; Kirsten, 2017; Carla, 2017; Sylia et al., 2019), while only two (2) studies`age samples were < 38years (Kim et al., 2008; Chenet al., 2008). This is evident that the studies considered studies involving Children and adolescents. However, most of the participants were adolescents as the ages were defined as $10-22$ years in the study.

\section{OVERALL RESULTS}

Studies on personality disorders on adolescents were considered from nineteen (19) articles from which factors such as higher odds of pain and physical illness and poorer physical health and a more rapid decline in physical health; depressive disorder, anxiety disorder, smoking and alcohol consumption, illicit substance use. Avoidance and internalized emotional dysregulation, characterized by preoccupying anxieties; Avoidance/abandonment, unstable interpersonal relationships, identity disturbance, impulsivity, suicidal and self-mutilating behaviours, etc., were said to show the effect of PD in adolescents. Scholars like (Ilaria et al., 2018; Patricia et al., 2016; Barbara De et al., 2003; Johnson et al., 2008; Sohye et al., 2014; Kim et al., 2008; Carla, 2017) identified Internalizing behaviour and Externalizing behaviour as the influential factors that might bring about Personality disorder in Adolescents. Meta-analyses indicated that internalizing behaviour and externalizing behaviour were both factors that determine personality disorder with approximately six times (i.e., 5.78) increased odds of a PD in Adolescents. Subanalysis comparing studies with Male $(\mathrm{n}=2)$ and Female $(\mathrm{n}=$ 7) samples indicated a significant effect. Moreover, this showed an increased risk of Internalizing behaviour and Externalizing behaviour in Adolescents samples. The pooled correlation of the studies indicated higher association ( $\mathrm{r}=$ $.095 ; 95 \% \mathrm{CI}=4.1 ; 1.1)$. However, Pro-social peers and antisocial peers were also considered (Thomas et al., 2001; Kirsten, 2017; Salome et al., 2017; Sylia et al., 2019). The majority of the studies were assessed through Child Behaviour Checklist, or Teacher's Report Form and Youth Self Report, except, Symptom scales for histrionic, borderline, and narcissistic personality disorders (Thomas et al., 2001) and Structured Assessment of Violence Risk in Youth (SAVRY) Kirsten (2017). Meta-analyses on antisocial peers indicated approximately five times (i.e., 4.46) increased odds of a PD in Adolescents. The pooled correlation of the studies indicated higher association $(\mathrm{r}=.095 ; 95 \% \mathrm{CI}=0.00,12.04)$.

However, factors such as depression, suicidal ideation, anxiety disorder, smoking and alcohol consumption, illicit substance use were also acknowledged as signs of personality disorder (Paul Moran et al., 2016; Kirsten, 2017; Eunice et al., 2017). The studies were assessed through Diagnostic Interview for Borderlines-Revised and the Childhood 
Interview for DSM-IV-TR BPD and control by Axis I and Axis II disorders. Meta-analyses on Depression and Suicidal ideation, anxiety disorder, smoking and alcohol consumption, illicit substance use indicated approximately six times (i.e., 6.25) increased odds of a PD in adolescents. The pooled correlation of the studies indicated higher association $(\mathrm{r}=$ $.067 ; 95 \% \mathrm{CI}=3.8 ; 1.1)$. Consideration was also on Avoidant/Abandonment, unstable interpersonal relationships, identity disturbance and impulsivity as defined by (Jean et al., 2018) and assessed through Diagnostic Interview for Borderlines-Revised and the Childhood Interview for DSMIV-TR BPD and on Axis I and Axis II disorders. Metaanalyses on Avoid abandonment, unstable interpersonal relationships, identity disturbance and impulsivity indicated approximately five times (i.e., 4.76) increased odds of a PD in adolescents. The pooled correlation of the studies indicated higher association $(\mathrm{r}=.099 ; 95 \% \mathrm{CI}=3.3 ; 1.5)$. Paranoid; Schizoid; Schizotypal; Antisocial; Obsessive-compulsive; Depressive; Passive-aggressive as defined by (Kirsten 2017) and assessed with Structured Assessment of Violence Risk in Youth (SAVRY), controlled by Structured Clinical Interview for DSM personality disorders and the Symptom Check List 90. Meta-analyses on Paranoid; Schizoid; Schizotypal; Antisocial; Obsessive-compulsive; Depressive; Passiveaggressive indicated approximately six times (i.e. 6.11) increased odds of a PD in Adolescents. The pooled correlation of the studies indicated higher association $(\mathrm{r}=.071 ; 95 \% \mathrm{CI}=$ $2.7 ; 1.2)$. Finally, only one study was obtained on Avoidant $\mathrm{PD}$ and internalized emotional dysregulation, characterized by preoccupying anxieties as a factor mitigating personality disorder in Adolescents. This was defined by (Gwen et al., 2012) and assessed with Psychopathy Checklist - Youth Version (PCL-YV) and the Structured Assessment of Violence Risk in Youth (SAVRY). Meta-analyses on Avoidance and internalized emotional dysregulation, characterized by preoccupying anxieties, indicated approximately four times (i.e. 4.35) increased odds of a PD in Adolescents. The pooled correlation of the studies indicated higher association $(\mathrm{r}=.082 ; 95 \% \mathrm{CI}=(3.7 ; 1.3)$. This strong and positive Correlation $(\mathrm{r}=.082 ; 95 \%)$ is evidence that Avoidance and internalized emotional dysregulation, characterized by preoccupying anxieties, significantly determine PD in Adolescents. Most of the factors were confirmed to be cogent determinants of personality disorders in Adolescents.

Psychotherapies those are often effective for adolescent's personality disorders.

\section{Behavioral therapy based on dialectical and cognitive principles.}

Cognitive Behavioural Therapy and Dialectical Behavioural Therapy have been widely developed for many groups, including adolescents. Cognitive Behavioural Therapy focuses on identifying and modifying negative thought patterns and improving disturbed behavioural self and social-regulation skills thought to underlie disorders.
An adolescent with a borderline personality disorder may be eligible for a modified form of the DBT known as Adolescent Emotional Control (AER) (Rathus, 2002). Adolescent DBT puts a little more emphasis on managing emotions and interpersonal relationships. This is because it was initially developed as a treatment for BPD, often marked by dramatic swings in mood and behaviour that can make having relationships with others difficult. Parents are more involved in the counselling program, emphasize the family, and teach fewer skills. (Rathus, 2002).

Improving the control of emotions can help create a System of training for emotional predictability and problem-solving (STEPPS; Blum 2009). This has proven to be successful with adolescents (Schuppert, 2009). Adolescents who had completed the STEPPS programme indicated having a greater sense of control over their mood swings. STEPPS uses programming for anyone close to adolescent, along with family, peers, and experts with common knowledge of skills, so that a community of people who are closer to a young person can strengthen and encourage newly learned skills.

This includes parent training, cognitive problem-solving training for young people, work-based parental and child programs, foster care, and family counselling. Many of these approaches are successful.

\section{Acceptance and Commitment Therapy}

ACT teaches skills to help individuals live and act in ways that are compatible with personal values while at the same time improving psychological resilience. ACT practitioners help individuals understand how their efforts to block, manipulate, and monitor emotional experiences generate difficulties. By identifying and solving these issues, individuals will become better able to make room for valuebased behaviours that promote well-being.

The basis of Acceptance and Commitment Therapy involves six fundamental concepts. They work together towards the critical objectives of successfully managing traumatic thoughts and memories and building a prosperous, vital life (Hayes, 2009). The principles are as follows:

- Acceptance.

- Cognitive Difusion.

- Being Present; Contact and connect with present moment

- Self as Context; The observing self

- Values; Values clarification

- Committed Action.

\section{A multisystemic approach}

Multisystemic therapy is used in adolescents and children at risk of developing antisocial behaviour. The intervention was conducted in various test trials with young people and their families and appeared successful. Care focuses on communication and parenting skills and strengthening pro- 
social interactions with peers and the school's success and the family and community (Henggeler et al., 2009).

Teenagers should be treated with therapies that deal with problems such as harassment and addiction. However, the fact that these treatments do not change the fundamental mechanisms of the personality remains uncertain. Since so many disordered personalities are related to a history of unsafe attachment, it seems essential to build a stable basis for treatment and help patients learn new ways of thinking and feeling about themselves and others. More recent studies have shown that attachment styles may exhibit different signs and behavioural problems in younger people.

\section{Parenting Style}

Moreover, parents teach empathy and respect character qualities such as integrity and compassion over being complex or dominant, modifying entitled attitudes, and avoiding entitled behaviour.

Construct healthy self-esteem (low self-esteem may also contribute to superiority and support one's ego using others). Parenting styles related to the development of narcissistic personality are often avoided, such as neglecting, indulgent (spoiling with privilege and belongings and fostering entitled attitudes) and cold, overcontrolled authoritarian approaches that focus on a child's perfection, winning, and toughness. Parents should also help their adolescents learn to identify narcissists to prevent or withstand their toxic damage. The capacity to think critically about what someone says or does, which begins to grow during puberty, is a necessary foundation for this. Critical thinking abilities allow one to distinguish lies from the facts and decide when someone manipulates or want to take advantage (Boucher, 1999).

Parents can give their children life-long defensive gifts of healthy levels of self-esteem and critical thinking abilities while squelching entitlement and narcissistic characteristics. Furthermore, parents and adolescents should not forget that there is no shame in getting help to get things done-it is a sign of courage, not weakness, in seeking information and assistance.

\section{CONCLUSIONS}

Many adolescents display this kind of behaviour to some degree, making it difficult to differentiate "normal" adolescent behaviour from a personality disorder. A significant clue is when the adolescent has recurrent issues or when these behaviours are getting more severe. Adolescents at risk of personality disorders may also be abusing substance, including alcohol, which also exacerbates depression or anxiety. Relationship issues, parental separation, familiarity with stressful events and other social or family stressors may also raise the likelihood of personality disorder.

Mental health practitioners are ideally qualified to carry out an assessment. Professional help may minimize the effects of personality disorders, although there is a range of more practical methods, such as school-based prevention services and community-based family intervention.

There is significant evidence that such psychological programs can reduce the symptoms of depression and anxiety in PD. Through mental health education, young people and their parents can recognize the signs that someone may have a problem. Such awareness may encourage parents to seek help from their children.

Educational programs often allow youth aware of the forms of assistance available to them that can be delivered online or by qualified educators. Prevention, early detection, and intervention of PD are essential to avoid long-term effects of PD on adolescents' overall functioning and interpersonal relationships. When diagnosing PD in adolescents, adequate and specialized personality disorders care must be provided.

The introduction of PD therapy in time and with a licensed therapist is highly successful, particularly during the adolescent phase, which has maximum remedial potential. On this basis, programs should be structured to respond early and to the adolescent community - home, school, and neighbourhood. Treatments for adolescents must improve their resilience, treat the condition, and create a prosocial identity. The focus needs to be changed to prevention in the form of programs for parents and caregivers. Environmental childhood trauma raises the risk of developing a wide variety of childhood and adolescence situations that may persist in adulthood. These disorders are expensive, not just for young people and their families but also for us.

Parental behaviours, such as bullying and harshness, are correlated with infant oppositional and violent behaviours (Stormshak et al., 2000), self-regulation deficits, and psychopathology (Egeland \& Sroufe, 1981; Larsson, Viding, Rijsdijk, \& Plomin, 2008; Rodriguez, Ayduk, et al., 2005; Sethi et al., 2000). Therefore, it is fair to assume that parental warmth and harshness can be positively and negatively correlated with personality development during adolescence.

Adolescent personality has significant genetics and environmental impact. "Nature, Nurture and Structure influence children personality traits" Olubukola Akanni. While the degree to which social factors affect personality, traits continue to be debated (Bleidorn, Kandler, Riemann, Angleitner, \& Spinath, 2009), several behavioural genetic studies have shown that $50 \%$ or more of the variation in personality characteristics arises from environmental influences (Loehlin, 1992). Earlier research indicates a significant shift in personality during puberty, as demonstrated by test-retest correlations (Roberts \& DE Vecchio, 2000). In the present inquiry, we suggest that parental characteristics and behaviour can be explained at least some of this shift.

In conclusion, it is also expected that parent personality can predict adolescent personality directly. There are two explanations for that assumption. First, behavioural genetic 
studies have shown that a substantial variation in personality traits arises from genetic factors (Loehlin, 1992). This finding is consistent with a positive relationship between parent and child personality. Secondly, it is also conceivable that parents and children's characteristics can be related separately from the parenting variables considered in this study through social learning processes. There should be further studies on how parental personality disorders determine children's personality traits and disorders and the impact on learning (formal and informal).

\section{REFERENCES}

[1] Aken , L. S. (2003). Predictors of withdrawal: Possible precursors of avoidant personality disorder. Development and Psychopathology, $21,815-838$

[2] Bakermans, K. (2008). Personality disorders in early adolescence and the development of later substance use disorders in the general population. Drug and Alcohol Dependence, 88S, S71-S84.

[3] Biskin RS, et., al. (2011). Outcomes in women diagnosed with borderline personality disorder in adolescence. Journal of the Canadian Academy of Child and Adolescent Psychiatry 20, 168-174.

[4] Chanen, A. M. \& McCutcheon, L., (2013). Borderline personality disorder in young people and the prospects for prevention and early intervention. Curr Psychiatry, (4), 48-57.

[5] Cooklin, M. (2013). Development of personality disorder symptoms and the risk for partner violence. Journal of Abnormal Psychology, $115,474-483$

[6] Ellis, L. K. (2008). Revision of the Early Adolescent Temperament Questionnaire. Poster presented at the biennial meeting of the Society for Research in Child Development, Minneapolis, MN.

[7] Galbally, W. (2011). The structure of temperament and personality in Russian children. Journal of Personality and Social Psychology, 71, 341-351.

[8] Ibrahim J, al. et. (2018). Childhood maltreatment and its link to borderline personality disorder features in children: A systematic review approach. Clinical Child Psychology and Psychiatry. 23(1): $57-76$.

[9] Ioana A.et al. (2017). Efficacy of Psychotherapies for Borderline Personality Disorder: A Systematic Review and Meta-analysis. JAMA Psychiatry. doi:10.1001/jamapsychiatry.

[10] Johnson, J. G., (2001). Adolescent personality disorders associated with violence and criminal behavior during adolescence and early adulthood. Am J Psychiat. (157); 1406-1412.

[11] Johnson, J. G., (2008). Personality disorder traits during adolescence and relationships with family members during the transition to adulthood. J Consult Clin Psych., (72), 923-932

[12] Kayla R. et., al (2019). Parenting and personality disorder: An overview and meta-synthesis of systematic reviews. School of Psychology, Illawarra Health and Medical Research Institute, University of Wollongong, Wollongong, New South Wales, Australia

[13] Kuperman, M. (1999). Assessment of abnormal personality in childhood: A Delphi survey of questionnaire data. Journal of Personality Disorders, 25, 89-100.

[14] Lahey, W. (1988). Personality diagnoses in adolescence: DSM-IV Axis II diagnoses and an empirically derived alternative. Am J Psychiat. 160: 952-966

[15] Lewis. T. (2001). Personality disorders associated with substance abuse among American and Greek adolescents. Adolescence. 37: $841-854$

[16] McGorry, C. H. (2013). Mentalization-based Treatment for selfharm in adolescents: a randomised control trial. J Am Acad Child Psy. in press

[17] Meins, H. (1997). The association between Axis I and Axis II psychiatric symptoms and high-risk sexual behavior during adolescence. J Pers Disord. 16: 73-94.

[18] Moffitt (2002). Personality disorders in children and adolescents. New York: Basic Books
[19] Moffitt, (2001). The stigmatization of mental illness in children and parents: developmental issues, family concerns, and research needs. J Child Psychol Psychiatry. 46(7):714-734.

[20] Moher D, et., al. (2009). Preferred reporting items for systematic reviews and meta-analyses: the PRISMA statement. Annals of Internal Medicine 151, 264-269.

[21] Nigg, R. (1997), Cluster A personality disorders: Schizotypal, schizoid, and paranoid personality disorders in childhood and adolescence. Journal of Psychopathology and Behavioral Assessment, 32, 515-528.

[22] Nijssens, J. (2013). Personality Disorders in Childhood and Adolescence. 2007, Hoboken: John Wiley \& Sons, Inc

[23] Perroud, F. (2014). The burden of disease among adolescents with personality pathology: Quality of life and costs. Journal of Personality Disorders, 26, 593-604

[24] Rathus, S., (2002). Prevalence and comorbidity of Axis I and Axis II disorders among treatment refractory adolescents admitted for specialized psychotherapy. J Pers Disord. 2011, 25: 842-850. 10.1521/pedi.2011.25.6.842.

[25] Reed GM, et. al. (2005). Operationalizing the international classification of functioning, disability and health in clinical settings. Rehabilitation Psychology 50, 122-131.

[26] Rosenstein, C. (1996). Categories versus dimensions in the classification and conceptualization of child and adolescent mental disorders-implications of recent empirical study. Journal of Child Psychology and Psychiatry, 53, 469-489.

[27] Royal College of Psychiatrists, (2011). The American Psychiatric Publishing textbook of personality disorders (pp. 143- 154). Washington, DC: American Psychiatric Publishing.

[28] Sarkar, H \&Adshead, S. (2006). Manual for the Schedule for Nonadaptive and Adaptive Personality-2 (SNAP-2). Minneapolis: University of Minnesota Press.

[29] Schuppert, G. (2009). Personality disorder assessment: The challenge of construct validity. Journal of Personality Disorders, 11, 205-231.

[30] Sethi et al., 2000). Children of mothers with borderline personality disorder: Identifying parenting behaviours as potential targets for intervention. Journal of Personality Disorders. 3(1): 76-91.

[31] Shonin, M. (2013). Stability and change in personality disorder. Current Directions in Psychological Science, 18, 27-31.

[32] Stormshak et al., 2000), The validity of DSM-III borderline personality disorder: a phenomenologic, family history, treatment responseand long-term follow-up study. Archives of General Psychiatry 40, 23-30.

[33] Sunderland, C. (2006). Assessment and diagnosis of personality disorder: Perennial issues and emerging conceptualization. Annual Review of Psychology, 58, 227-257.

[34] Sved Williams AE, et. al. (2018) A new therapeutic group to help women with borderline personality disorder and their infants. Journal of Psychiatric Practice.; 24 (5): 331-340

[35] Van, I. (1999). Temperament as a unifying basis for personality and psychopathology. Journal of Abnormal Psychology, 114, 505-521.

[36] Van, I. (2011). Precursors and diverse pathways to personality disorder in children and adolescents. Development and Psychopathology, 21, 683-685.

[37] Vanyukov, S. (1993). An overview of developmental psychopathology. In P. Zelazo (Ed.), Oxford handbook of developmental psychology (pp. 455-480). New York: Oxford University Press.

[38] Wachikwu, H. \&Ibegbunam, D. (2012). Developmental psychopathology: Reactions, reflections, projections. Developmental Review, 13, 471-502.

[39] Winograd G, Cohen P, Chen H (2008). Adolescent borderline symptoms in the community: prognosis for functioning over 20 years. Journal of Child Psychology and Psychiatry 49, 933-941.

[40] Winsper, C., et al. (22015). The aetiology of borderline personality disorder (BPD): contemporary theories and putative mechanisms. Current Opinion in Psychology. 21: 105-110.

[41] Wolff, S. (1968), Adolescent personality disorders and conflict with romantic partners during the transition to adulthood. Journal of Personality Disorders, 18, 507-525. 
[42] Yates, H (2003). Adolescent Axis I and personality disorders predict quality of life during young adulthood. J Adolescent Health. (39); 1419

[43] Zanarini, F. et., al., (2001). Personality disorders from the perspective of child and adolescent psychiatry. Severe personality disorders: everyday issues in clinical practice. New York: Cambridge University Press, 79-92.

[44] Chen, H., Cohen, P., Crawford, T. N., Kasen, S., Guan, B., \&Gorden, K. (2009). Impact of early adolescent psychiatric and personality disorder on long-term physical health: A 20-year longitudinal followup study. Psychological medicine, 39(5), 865.

[45] Moran, P., Leese, M., Lee, T., Walters, P., Thornicroft, G., \& Mann, A. (2003). Standardised Assessment of Personality-Abbreviated Scale (SAPAS): preliminary validation of a brief screen for personality disorder. The British Journal of Psychiatry, 183(3), 228232.

[46] Adshead, G., Brodrick, P., Preston, J., \& Deshpande, M. (2012). Personality disorder in adolescence. Advances in psychiatric treatment, 18(2), 109-118.

[47] De Clercq, B., \& De Fruyt, F. (2003). Personality disorder symptoms in adolescence: A five-factor model perspective. Journal of Personality Disorders, 17(4), 269-292.

[48] Kim, S., Sharp, C., \& Carbone, C. (2014). The protective role of attachment security for adolescent borderline personality disorder features via enhanced positive emotion regulation strategies. Personality Disorders: Theory, Research, and Treatment, 5(2), 125.

[49] Johnson, J. G., Cohen, P., Kasen, S., Skodol, A. E., \& Oldham, J. M. (2008). Cumulative prevalence of personality disorders between adolescence and adulthood. Acta Psychiatrica Scandinavica, 118(5), 410-413.

[50] Johnson, J. G., Cohen, P., Kasen, S., Skodol, A. E., Hamagami, F., \& Brook, J. S. (2000). Age-related change in personality disorder trait levels between early adolescence and adulthood: A community-based longitudinal investigation. Acta Psychiatrica Scandinavica, 102(4), $265-275$

[51] Reising, K., Farrington, D. P., Ttofi, M. M., Piquero, A. R., \&Coid, J. W. (2019). Childhood risk factors for personality disorder symptoms related to violence. Aggression and violent behavior, 49, 101315.

[52] Hauber, K., Boon, A. E., \&Vermeiren, R. (2017). Examining changes in personality disorder and symptomology in an adolescent sample receiving intensive mentalization based treatment: a pilot study. Child and adolescent psychiatry and mental health, 11(1), 1-7.

[53] See, A. Y., Klimstra, T. A., Shiner, R. L., \&Denissen, J. J. (2020). Linking narrative identity with schizotypal personality disorder features in adolescents. Personality Disorders: Theory, Research, and Treatment.

[54] Pickard, H. (2011). Responsibility without blame: Empathy and the effective treatment of personality disorder. Philosophy, psychiatry, \& psychology: PPP, 18(3), 209.

[55] Beck, A. T., Davis, D. D., \& Freeman, A. (Eds.). (2015). Cognitive therapy of personality disorders. Guilford Publications.

[56] Rodríguez-Ferreiro, J., Aguilera, M., \& Davies, R. (2020). Positive schizotypy increases the acceptance of unpresented materials in false memory tasks in non-clinical individuals. Frontiers in psychology, 11, 262.

[57] Esterberg, M. L., Goulding, S. M., \& Walker, E. F. (2010). Cluster A personality disorders: schizotypal, schizoid and paranoid personality disorders in childhood and adolescence. Journal of Psychopathology and Behavioral Assessment, 32(4), 515-528.

[58] Fountoulakis, K. N., Leucht, S., \&Kaprinis, G. S. (2008). Personality disorders and violence. Current opinion in psychiatry, 21(1), 84-92.

[59] Lykken, D. T. (1995). The antisocial personalities. Psychology Press.

[60] Black, D. W. (2013). Bad boys, bad men: Confronting antisocial personality disorder (sociopathy).

[61] McGee, T. R., Hayatbakhsh, M. R., Bor, W., Aird, R. L., Dean, A. J., \&Najman, J. M. (2015). The impact of snares on the continuity of adolescent-onset antisocial behaviour: A test of Moffitt's developmental taxonomy. Australian \& New Zealand Journal of Criminology, 48(3), 345-366.
[62] Wolfe, D. A., Jaffe, P. G., \& Crooks, C. V. (2008). Adolescent risk behaviours: Why teens experiment and strategies to keep them safe. Yale University Press.

[63] Adeusi, S. O. (2013). Efficacy of cognitive restructuring and behavioural rehearsal on conduct disorder in adolescents in Special Correctional Centres in Lagos State (Doctoral dissertation, Covenant University, Ota, Ogun State).

[64] Blagov, P. S., \&Westen, D. (2008). Questioning the coherence of histrionic personality disorder: Borderline and hysterical personality subtypes in adults and adolescents. The Journal of nervous and mental disease, 196(11), 785-797.

[65] Cale, E. M., \& Lilienfeld, S. O. (2002). Histrionic personality disorder and antisocial personality disorder: Sex-differentiated manifestations of psychopathy? Journal of personality disorders, 16(1), 52-72.

[66] Pincus, A. L., \&Lukowitsky, M. R. (2010). Pathological narcissism and narcissistic personality disorder. Annual review of clinical psychology, 6, 421-446.

[67] Baumeister, R. F., Catanese, K. R., \& Wallace, H. M. (2002). Conquest by force: A narcissistic reactance theory of rape and sexual coercion. Review of general psychology, 6(1), 92-135.

[68] Baskin-Sommers, A., Krusemark, E., \&Ronningstam, E. (2014). Empathy in narcissistic personality disorder: from clinical and empirical perspectives. Personality Disorders: Theory, Research, and Treatment, 5(3), 323.

[69] Ronningstam, E. (2005). Identifying and understanding the narcissistic personality. Oxford University Press.

[70] Pitsch, J. P. (2009). Reports of group differences in narcissism within the practice of Buddhist Satipatthana Vipassana meditation: Experiences of self-centeredness, grandiosity, the need for mirroring/admiration, and emptiness. Institute of Transpersonal Psychology.

[71] Beauchaine, T. P., Klein, D. N., Crowell, S. E., Derbidge, C., \&Gatzke-Kopp, L. (2009). Multifinality in the development of personality disorders: A Biologyx Sex $x$ Environment interaction model of antisocial and borderline traits. Development and psychopathology, 21(3), 735.

[72] Choi-Kain, L. W., Fitzmaurice, G. M., Zanarini, M. C., Laverdière, O., \&Gunderson, J. G. (2009). The relationship between self-reported attachment styles, interpersonal dysfunction, and borderline personality disorder. The Journal of nervous and mental disease, 197(11), 816-821.

[73] Levy, K. N. (2005). The implications of attachment theory and research for understanding borderline personality disorder. Development and psychopathology, 17(4), 959-986.

[74] Lawson, C. A. (2002). Understanding the borderline mother: Helping her children transcend the intense, unpredictable, and volatile relationship. Rowman \& Littlefield.

[75] Fineberg, N., Day, G. A., de Koenigswarter, N., Reghunandanan, S., Kolli, S., Jefferies-Sewell, K., ... \& Laws, K. R. (2015). The neuropsychology of obsessive-compulsive personality disorder: a new analysis. CNS spectrums.

[76] (Royal College of Psychiatrists 2011

[77] Crews, F., He, J., \& Hodge, C. (2007). Adolescent cortical development: a critical period of vulnerability for addiction. Pharmacology Biochemistry and Behavior, 86(2), 189199.

[78] Rice, F., Harold, G. T., Boivin, J., Van den Bree, M., Hay, D. F., \& Thapar, A. (2010). The links between prenatal stress and offspring development and psychopathology: disentangling environmental and inherited influences. Psychological medicine, 40(2), 335-345.

[79] Frick, P. J. (1994). Family dysfunction and the disruptive behavior disorders. Advances in clinical child psychology, 203-226.

[80] Gershoff, E. T. (2002). Corporal punishment by parents and associated child behaviors and experiences: a meta-analytic and theoretical review. Psychological bulletin, 128(4), 539.

[81] Biederman, J., Faraone, S. V., Hirshfeld-Becker, D. R., Friedman, D., Robin, J. A., \& Rosenbaum, J. F. (2001). Patterns of psychopathology and dysfunction in high-risk children of parents with panic disorder and major depression. American Journal of Psychiatry, 158(1), 49-57. 
[82] Battle, C. L., Shea, M. T., Johnson, D. M., Yen, S., Zlotnick, C., Zanarini, M. C., ... \& Morey, L. C. (2004). Childhood maltreatment associated with adult personality disorders: findings from the Collaborative Longitudinal Personality Disorders Study. Journal of personality Disorders, 18(2), 193-211.

[83] Fruzzetti, A. E., Shenk, C., \& Hoffman, P. D. (2005). Family interaction and the development of borderline personality disorder: A transactional model. Development and psychopathology, 17(4), 1007-1030.

[84] Hayes, S. C., Strosahl, K. D., \& Wilson, K. G. (2009). Acceptance and commitment therapy. Washington, DC: American Psychological Association.
[85] Henggeler, S. W., Schoenwald, S. K., Borduin, C. M., Rowland, M. D., \& Cunningham, P. B. (2009). Multisystemic therapy for antisocial behavior in children and adolescents. Guilford Press.

[86] Boucher, C. R. (1999). Students in discord: Adolescents with emotional and behavioral disorders. Greenwood Publishing Group.

[87] Laurenssen, E. M. P., Hutsebaut, J., Feenstra, D. J., Van Busschbach, J. J., \&Luyten, P. (2013). Diagnosis of personality disorders in adolescents: a study among psychologists. Child and adolescent psychiatry and mental health, 7(1), 1-4. 